\title{
Edyta Wójcicka*
}

iD https://orcid.org/0000-0003-1799-143X

\section{Lektura szkolna jako nośnik wartości Na przykładzie powieści Johna Ronalda Reuela Tolkiena Hobbit, czyli tam i z powrotem}

Utwory Tolkiena obrazują ciagle aktualne idee (mityczne „wieczne teraz”) dramatyczność życia: walki, które się w nim toczą o podstawowe wartości, jak odwaga, poświęcenie, lojalność, przeciw okrucieństwu i zniszczeniu, dobra ze złem, ukazuja zwycięstwo sprytu, odwagi, lojalności. Na poziomie tych uniwersalnych idei utwory Tolkiena wykraczaja poza literaturę dziecięca. Anna Brzozowska-Krajka ${ }^{1}$

Temat i treść mojego artykułu nawiązują do zagadnień aksjologicznych wpisanych w cele i zadania edukacji polonistycznej uczniów szkoły ponadpodstawowej. W moim przekonaniu problematyka ta jest niezwykle ważna w kontekście odczuwanego obecnie kryzysu wartości, autorytetów, powszechnie uznawanych norm i zasad postępowania. W sposób szczególny na niebezpieczne konsekwencje oddziaływania tych zjawisk narażone jest młode pokolenie, tzn. osoby będące na etapie intensywnego poszukiwania sensu życia i konstruowania tożsamości, tj. w okresie adolescencji. Stąd tak ważne okazują się oddziaływania - w tym edukacyjne i lekturowe - dzięki którym możliwe staje się poszukiwanie odpowiedzi na fundamentalne pytania, związane z ludzką egzystencją, a dotyczące m.in. wartości niezbędnych dla świadomego funkcjonowania w kulturze.

* Mgr, Uniwersytet Marii Curie-Skłodowskiej, Wydział Humanistyczny, Katedra Edukacji Polonistycznej, Plac Marii Curie-Skłodowskiej 4A, 20-033 Lublin, edyta.woj@wp.pl

1 Słownik literatury popularnej, red. T. Żabski, Wydawnictwo Towarzystwo Przyjaciół Polonistyki Wrocławskiej, Wrocław 2006, s. 609-610. 
Przedmiotem mojego zainteresowania jest próba odpowiedzi na pytanie, czy i jak szkolna edukacja polonistyczna może wspierać nastoletnich uczniów w ich drodze ku dorosłości. Jaką rolę odgrywają w tym wartości, których nośnikami są - zgodnie z przyjętymi tu przeze mnie założeniami teoretyczno-metodologiczny$\mathrm{mi}^{2}$ i dydaktycznymi ${ }^{3}$ - szkolne lektury, wśród nich utwory z kręgu literatury fantastycznej o znaczącym potencjale i oddziaływaniu kulturotwórczym, aksjonormatywnym i formacyjnym ${ }^{4}$. Jakie rozwiązania metodyczne mogą sprzyjać, a jakie nie w realizacji celów i zadań związanych z edukacją aksjologiczną?

Zanim spróbuję odpowiedzieć na tak postawione pytania, chciałabym przywołać kilka ogólnych założeń dotyczących aksjologicznej koncepcji dzieła literackiego. Problematyka aksjologiczna w literaturze i w edukacji kulturowo-literackiej jest jedną z bardziej eksponowanych we współczesnym dyskursie naukowym i edukacyjnym, czego potwierdzeniem są publikacje o charakterze monograficznym ${ }^{5}$, liczne artykuły, a także wydane po sympozjach naukowych publikacje poświęcone tej tematyce ${ }^{6}$ Z teoretycznych ustaleń znawców interesującej mnie

2 Zob. seria „Literatura w Kręgu Wartości”, np. Prawda w literaturze. Studia, red. A. Tyszczyk, J. Borowski, I. Piekarski, Towarzystwo Naukowe Katolickiego Uniwersytetu Lubelskiego, Lublin 2009; Problematyka aksjologiczna w nauce o literaturze. Studia, red. S. Sawicki, A. Tyszczyk, Wydawnictwo KUL, Lublin 1992.

3 Zob. np.: B. Chrząstowska, Wartości odkrywane, narzucone i postulowane w szkolnej edukacji polonistycznej, w: Polonistyka w przebudowie. Literaturoznawstwo - wiedza o języku - wiedza o kulturze - edukacja, red. M. Czermińska i in., t. 2, Universitas, Kraków 2005, s. 306-322; Czytanie tekstów kultury. Metodologia - badania - metodyka, red. B. Myrdzik, I. Morawska, Wydawnictwo UMCS, Lublin 2007; M. Kwiatkowska-Ratajczak, Z perspektywy wartości o prozie dla dzieci i młodzieży, Wydawnictwo Nakom, Poznań 1994; I. Morawska, Rola literatury w edukacji patriotycznej uczniów szkoły podstawowej (1944-1989), Wydawnictwo UMCS, Lublin 2005; B. Myrdzik, Zrozumieć siebie i świat. Szkice i studia o edukacji polonistycznej, Wydawnictwo UMCS, Lublin 2006; A. Smuszkiewicz, Fantastyka i pajdologia. Studia i szkice, Poznańskie Studia Polonistyczne, Poznań 2013; Z.A. Kłakówna, Kulturowa koncepcja kształcenia polonistycznego, w: Polonistyka w przebudowie. Literaturoznawstwo - wiedza o języku - wiedza o kulturze - edukacja, red. M. Czermińska i in., t. 2, Universitas, Kraków 2005, s. 74-84; Tejże, Przymus i wolność. Projektowanie procesu kształcenia kulturowej kompetencji, Wydawnictwo Edukacyjne, Kraków 2003; M. Wróblewski, „Czytanie przyszłości”. Polska fantastyka naukowa dla młodego odbiorcy, Wydawnictwo Naukowe UMK, Toruń 2008.

4 Por. E. Korulska, Hobbit, czyli Wielka Przygoda z lektura, Wydawnictwo Edukacyjne, Kraków 1998; A. Smuszkiewicz, Edukacyjne wartości fantastyki, „Forum Humanistów” 2001, nr 2, s. 70-76.

5 Spośród licznych prac monograficznych klasyczne dzisiaj pozycje stanowią: Język wartości J. Puzyniny (Państwowe Wydawnictwo Naukowe, Warszawa 1992) oraz Język - wartości - polityka: zmiany rozumienia nazw wartości w okresie transformacji ustrojowej w Polsce, pod. red. J. Bartmińskiego (Wydawnictwo UMCS, Lublin 2006). Ważną pozycję stanowi też seria poświęcona problematyce aksjologicznej: „Studia Etyczne i Estetyczne”, pod red. T. Szkołuta (zbiór 1-5, Wydawnictwo UMCS, Lublin 1994-1999).

6 W roku 1982 z inicjatywy S. Sawickiego Katedra Teorii Literatury Katolickiego Uniwersytetu Lubelskiego zorganizowała z udziałem najwybitniejszych polonistów i filozofów pionierskie 
problematyki wynika, że nośnikami wartości w dziele literackim może być język utworu oraz „elementy tekstu głównego: inwokacje, pointy, [...], cytaty, [...], jak i te, które należą do najbliższej metatekstowej sfery utworu: tytuły, dedykacje, motta"', a także elementy świata przedstawianego w utworze, a zatem: przestrzeń, czas, zdarzenia, postaci. Zdaniem Stefana Sawickiego aksjologiczne odczytywanie literatury „dokonuje się przede wszystkim poprzez badanie relacji między postaciami literackimi, podmiotem mówiącym i autorem a rzeczywistością w dziele przedstawionym" ${ }^{\prime \prime}$. Koncepcje aksjologicznego czytania dzieł literackich aplikowane są przez dydaktyków i znajdują potwierdzenie w opracowaniach teoretycznych dotyczących strategii kształcenia kulturowo-literackiego, zwłaszcza na lekcjach poświęconych szkolnym lekturom. Dydaktycy podkreślają, że literatura nie tylko ułatwia odkrywanie i doświadczanie wartości, posiada także ogromny potencjał poszerzania horyzontów myślowych, jest źródłem „poznania i samopoznania”, wpływa na zwiększanie wrażliwości moralnej, jest źródłem mądrości ${ }^{10}$. To uzasadnia obecność tekstów literackich w procesie realizacji zadań edukacyjnych, a kluczową rolę $\mathrm{w}$ organizowaniu sytuacji lekturowych przyznaje się szkolnemu poloniście, jego kompetencjom, wrażliwości i kulturze pedagogicznej"1.

sympozjum „Wartościowanie i ocena w badaniach literackich”; pokonferencyjna publikacja O wartościowaniu w badaniach literackich. Studia, pod red. S. Sawickiego i W. Panasa (Wydawnictwo KUL, Lublin 1986) zapoczątkowała kontynuowaną po dziś dzień serię „Literatura w Kręgu Wartości", z której nie sposób pominąć co najmniej kilku pozycji: Interpretacje aksjologiczne, pod red. W. Panasa, A. Tyszczyka (Wydawnictwo KUL, Lublin 1997), Wartość i sens. Aksjologiczne aspekty teorii interpretacji, pod red. E. Fiały, A. Tyszczyka, R. Zajączkowskiego (Wydawnictwo KUL, Lublin 2003), Słowo - wartość - kultura J. Puzyniny (Towarzystwo Naukowe Katolickiego Uniwersytetu Lubelskiego, Lublin 1998). Pokłosiem ogólnopolskiego konwersatorium „Język a kultura", organizowanego przez Uniwersytet Wrocławski, są cztery pozycje: Język a kultura. t. 1: Podstawowe pojęcia i problemy, pod red. J. Anusiewicza i J. Bartmińskiego (Wyd. Wrocław: Wiedza o Kulturze, Wrocław 1991), Język a kultura, t. 2: Zagadnienia leksykalne i aksjologiczne, pod red. J. Puzyniny i J. Bartmińskiego (Wyd. Wrocław: Wiedza o Kulturze, Wrocław 1991), Język a kultura, t. 3: Wartości w języku i tekście, red. J. Puzynina, J. Anusiewicz, (Wyd. Wrocław: Wiedza o Kulturze, Wrocław 1991) oraz Język w kręgu wartości. Studia semantyczne, pod red. J. Bartmińskiego (Wydawnictwo UMCS, Lublin 2003).

7 S. Sawicki, Aksjologiczne..., s. 300.

8 S. Sawicki, Problematyka aksjologiczna..., s. 99.

9 Zob. R. Handke, Lektura jako poznanie i samopoznanie, w: Podmiotowy wymiar szkolnej polonistyki (materiały z konferencji: Antropocentryczno-kulturowy nurt w kształceniu polonistycznym), red. Z. Uryga, Wydawnictwo Naukowe Wyższej Szkoły Pedagogicznej, Kraków 1998, s. 97-104.

10 Zob. B. Myrdzik, Lektura jako źródło mądrości, w: Problemy poznawania dzieła literackiego w szkole, red. T. Świętosławska, Wydawnictwo UŁ, Łódź 2001, s. 24-33.

11 Por. B. Myrdzik, Nauczyciel jako organizator dialogu ucznia z tradycja, w: Nowoczesność i tradycja w ksztatceniu literackim. Podręcznik do ćwiczeń z metodyki języka polskiego, red. tejże, Wydawnictwo UMCS, Lublin 2000, s. 175-187. 
Problematyka odpowiedzialności nauczyciela przygotowującego młodych ludzi do wyboru wartości wpisuje się także w badania autorów licznych publikacji krakowskiej serii „Edukacja nauczycielska polonisty”'2. W książce Szkolne spotkania $z$ literatura stawiają ważne i nadal aktualne pytania: w jaki sposób pracować z lekturą szkolną, by praca ta zachęcała młodych ludzi do sięgania także po propozycje pozaszkolne, by uczyła dokonywania wyborów i czerpania przyjemności ze spotkania z literacką przygodą? Autorzy włączają się również w ważne aktualnie dyskusje o potrzebie istnienia kanonu, poruszają problematykę obejmującą kształcenie umiejętności wartościowania literatury, zwracają uwagę na aspekty aksjologiczne kształcenia językowego, a także wartościowanie pracy nauczyciela ${ }^{13}$.

O tym, że jednym $z$ ważniejszych zadań edukacyjnych współczesnej szkoły jest wprowadzenie młodego człowieka $\mathrm{w}$ świat fundamentalnych wartości kulturowych, przekonują także zapisy w aktualnych dokumentach oświatowych. Zarówno w podstawie programowej z 2009, jak i nowej z 2017 roku określono zadania nauczyciela języka polskiego, do których należy m.in. „prowadzanie uczniów $\mathrm{w}$ tradycję i sferę wartości narodowych oraz kształtowanie postawy otwartości wobec innych kultur"14, a także

Kształtowanie umiejętności uczestniczenia w kulturze polskiej i europejskiej, szczególnie w jej wymiarze [...] aksjologicznym oraz rozwijanie zdolności dostrzegania prawdy, dobra, piękna, szacunku dla człowieka i kierowania się tymi wartościami ${ }^{15}$.

Przytoczone dokumenty uzmysławiają, że „aksjologia edukacyjna wpisana jest w proces kształcenia"'16, a uczeń w wieku dorastania powinien otrzymać w szkole wsparcie niezbędne do rozpoznania i zrozumieniu wartości, których nośnikami są lektury omawiane na lekcjach języka polskiego.

12 Cykl wyróżnia się szerokim spektrum zagadnień poruszanych w kolejnych tomach, co dowodzi, iż autorzy - dydaktycy, literaturoznawcy, językoznawcy - dostrzegają konieczność wspierania nauczycieli w niełatwej rzeczywistości edukacyjnej XXI wieku - czasach nowych wyzwań, nowych zadań, ale i nowych zagrożeń. Zob. np. Wartościowanie a edukacja polonistyczna, red. A. Janus-Sitarz, Universitas, Kraków 2008; Tejże, Przyjemność i odpowiedzialność w lekturze. O praktykach czytania literatury w szkole, Universitas, Kraków 2009.

13 Zob. też.: Edukacja polonistyczna. Metamorfozy kontekstów i metod, red. M. Karwatowska, L. Tymiakin, Wydawnictwo UMCS, Lublin 2017; Edukacja polonistyczna wobec przemian kulturowych, red. I. Morawska, M. Latoch-Zielińska, Wydawnictwo UMCS, Lublin 2017.

14 Podstawa programowa z komentarzami. Język polski, t. 2, Ministerstwo Edukacji Narodowej, Warszawa 2009, s. 34.

15 Podstawa programowa. Język polski. Szkoła podstawowa - klasy IV-VIII, Ministerstwo Edukacji Narodowej, Warszawa 2017, s. 1.

16 B. Chrząstowska, Wartości..., s. 306. 
Przypisywanie funkcji wychowawczej literaturze jest w pełni uzasadnione, gdyż - jak pisze Bożena Chrząstowska, wybitny dydaktyk literatury i znawca szkolnej edukacji kulturowo-literackiej - wychowywać uczniów „ku wartościom” można tylko „drogą trudnej pracy wdrażania ich do obcowania z wielką tradycją literatury narodowej i europejskiej”, a „kultura popularna, masowa stanowi pożyteczny próg, na który wchodzimy, by znaleźć się w przestrzeni kultury wysokiej”’17. Zakłada się, że właściwie zorganizowana edukacja aksjologiczna, rozumiana jako „nauczanie o sposobach traktowania wartości, wartościowania, o sposobach ich uzasadniania, a także o uwarunkowaniach i konsekwencjach różnych postaw wobec wartości”»18, pozwala nauczycielowi nie tylko wprowadzić ucznia w świat wartości i pomóc mu je dojrzeć, nazwać, zrozumieć i zaakceptować ${ }^{19}$, także zmotywować do uzewnętrznienia. W nawiązaniu do aksjologicznej koncepcji czytania literatury chcę odnieść się do obecności fantastyki w dydaktyce języka polskiego ${ }^{20}$ na przykładzie powieści Johna Ronalda Reuela Tolkiena ${ }^{21}$ Hobbit, czyli tam i z powrotem ${ }^{22}$.

Powszechnie uznaje się, że właśnie lekcje języka polskiego mogą sprzyjać kształtowaniu ludzi refleksyjnych, którzy świadomie i z uwagą odczytują teksty literackie, bo to między innymi dzięki nim człowiek kształtuje swój świat wartości. Ważną rolę w tym procesie mogą odegrać lektury zarówno z kręgu ścisłego kano$\mathrm{nu}$, ale także spoza listy szkolnych propozycji.

O rekomendowanych sposobach postępowania dydaktycznego wobec lektur szkolnych jako narzędzi stosowanych w edukacji aksjologicznej pisze autorka

17 Tamże, s. 311.

18 K. Olbrycht, Prawda, dobro i piękno w wychowaniu człowieka jako osoby, Katowice 2002, s. 89. Zob. także: Seria „Edukacja Aksjologiczna”, red. K. Olbrycht, tomy 1-4, Katowice, Wydawnictwo UŚ: Wymiary - kierunki - uwarunkowania, t. 1, Katowice 1994; Odpowiedzialność pedagoga, t. 2, Katowice 1995; O tolerancji, t. 3, Katowice 1995; Wybrane problemy przekazu wartości, t. 4, Katowice 1999.

19 Zdaniem wielu dydaktyków akceptacja wartości jest możliwa wówczas, gdy nikt inny (np. rodzic lub nauczyciel) nie będzie narzucał wartość, które są obce lub niemożliwe do zaakceptowania na danym poziomie indywidualnego rozwoju. Por. B. Chrząstowska, Wartości..., s. 306-322; B. Myrdzik, O poznawaniu i doświadczaniu wartości w procesie edukacyjnym, w: Zrozumieć siebie i świat, s. 102.

20 Na temat obecności literatury fantastycznej w edukacji szkolnej pisze A. Smuszkiewicz, Fantastyka w gimnazjum, w: Horyzonty polonistyki. W kręgu edukacji, języka i kultury, red. M. Karwatowska, M. Latoch-Zielińska, I. Morawska, Wydawnictwo UMCS, Lublin 2010, s. 143-159.

21 Zob. studia krytycznoliterackie nad twórczością tego autora, np.: Cz. Miłosz, Hobbit: bohater XX w., „Tygodnik Powszechny” 2002, nr 8, s. 9; K. Sokołowski, Fenomen Tolkiena, „Fantastyka” 1985, nr 2, s. 5; M. Skórska, Powrót wyobraźni symbolicznej. Fantasy jako wspótczesny wyraz mitologicznych i archetypicznych potrzeb człowieka, „Nowa Fantastyka” 1990, nr 2, s. 60; J.R.R. Tolkien - recepcja polska: studia i eseje, red. J.Z. Lichański, Wydawnictwo UW, Warszawa 1996.

22 J.R.R. Tolkien, Hobbit, czyli tam i z powrotem, przeł. M. Skibniewska, Wydawnictwo Iskry, Warszawa 1997. 
rozważań o Wartościach odkrywanych, narzucanych i postulowanych w szkolnej edukacji polonistycznej. Badaczka sugeruje polonistom zachować „wstępną neutralność aksjologiczną” i przypomina, że jeśli wartości „pojawią się na lekcji języka polskiego narzucone drogą arbitralnego komunikowania, nie realizują się, nie mają szans na "urzeczywistnienie», [...] zostają odrzucone"23. Warto zatem, jak radzi Chrząstowska, zainicjować takie aktywności czytania tekstu kultury i „myślenia według wartości”, które pozwolą wyjść poza rozpoznanie wstępne - intuicyjne i emocjonalne. A temu nie służy także powierzchowne i pospieszne czytanie, gdyż urzeczywistnienie wartości jest zawsze efektem rzetelnej pracy nad tekstem i skutkiem pogłębionego przeżycia ${ }^{24}$.

O tym, że literatura może być ważnym narzędziem wspomagającym rozwój młodego człowieka przekonują również autorzy publikacji Książka i młody czytelnik, którzy piszą:

Istotą sztuki, także książki dla [...] młodych odbiorców, jest prowadzenie wewnętrznego dialogu, budzenie wrażliwości i refleksyjności. Lektura, choć wymaga wysiłku, jest przecież - paradoksalnie - „nic-nie-robieniem”. Ale to nie są wakacje od myślenia, przeciwnie: to właśnie czas głębokiego skupienia, kiedy ścieżki życia zaczynają się prostować, a życie odsłania swój głęboko skrywany sens. [...] Akt lekturowy prowadzi ku doświadczaniu sensu. I to jest zasadniczy walor książki, który lekturę czyni niezbędnym ogniwem rozwoju dziecka, wiecznie żywym źródłem jego humanitas ${ }^{25}$.

Zanim jednak przedstawię propozycję różnorodnych form aktywności - tak nauczyciela, jak i ucznia w ramach omawiania lektury szkolnej - chciałabym odnieść się do kwestii wartości i wartościowania. Uporządkowanie wiedzy aksjologicznej w aspekcie edukacyjnym wydaje się zasadne, gdyż - jak podkreśla Maria Kwiatkowska-Ratajczak - „aby prezentować dzieciom i młodzieży świat wartości, trzeba najpierw zdać sobie sprawę z tego, co wiemy, a czego nie wiemy o wartościach"26.

Zagadnienie wartości - powszechnie uznawane za jedno z trudniejszych i wysoce skomplikowanych problemów filozofii - stało się w ostatnich dekadach bardzo częstym elementem prac badaczy wielu dyscyplin naukowych ${ }^{27}$. Również nasi-

23 B. Chrząstowska, Wartości..., s. 307.

24 Por. tamże, s. 312.

25 G. Leszczyński, M. Zając, Książka i młody czytelnik: zbliżenia, oddalenia, dialogi. Studia i szkice, Wydawnictwo Stowarzyszenia Bibliotekarzy Polskich, Warszawa 2013, s. 56-57.

26 M. Kwiatkowska-Ratajczak, Z perspektywy wartości..., s. 23.

27 Oto kilka wybranych ostatnich pozycji na temat wartości: P. Brzozowski, Wzorcowa hierarchia wartości. Polska, Europejska czy uniwersalna?, Wydawnictwo UMCS, Lublin 2007; W. Cichoń, Wartość - człowiek - wychowanie. Zarys problematyki aksjologiczno-wychowawczej, Wydawnictwo UJ, Kraków 1996; J. Gajda, Wartości w życiu człowieka. Prawda, miłość, samotność, Wydawnictwo UMCS, Lublin 1997; M. Jankowska, J. Krasoń, Hierarchia wartości i sposoby ich 
lone podejmowane próby poszukiwania przez człowieka wartości uniwersalnych, trwałych, niezmiennych dowodzą rosnącego zainteresowania etyką i wartościami. $\mathrm{W}$ publikacjach poświęconych zagadnieniom aksjologicznym w kulturze i edukacji odnaleźć można różnorakie rozumienie istoty pojęcia wartości, co wynika z podstawowych koncepcji przyjętych przez badaczy, w tym koncepcji człowieka, świata, bytu. Nie rozwijając tej myśli, warto stwierdzić, iż zdecydowana większość badaczy odwołuje się koncepcji obiektywistycznej, której zwolennicy wartości uznają za trwałe, uniwersalne, niezależne od ludzkiej świadomości.

$\mathrm{Z}$ punktu widzenia edukacji aksjologicznej szczególnie istotne są ustalenia dydaktyków i językoznawców ${ }^{28}$. Powszechnie uznaje się, że nie istnieje jednolity świat wartości, lecz różnorodne typy wartościowań, konstytuujące różne kategorie wartości, a każdy człowiek przeżywa wartości w sobie tylko właściwy sposób. Sam termin wartość, mimo że obecnie tak często używany i wywołujący wiele kontrowersji, nie jest łatwy do zdefiniowania. Na pytanie o istotę wartości otrzymamy wiele różnych odpowiedzi z uwagi na szeroki zakres pojęciowy i wieloznaczność terminu.

Czym zatem jest wartość w świetle ustaleń badawczych językoznawców zajmujących się tą problematyką? Za autorką Języka wartości należy przyjąć, iż „wartości w sensie prymarnym to szeroko rozumiane cechy przedmiotów, sytuacji, innych cech, które uznajemy intelektualnie za dobre i/lub odczuwamy jako dobre, a odpowiednio antywartości to cechy, które uznajemy za złe i/lub odczuwamy jako takie"29. Wartościowanie zaś w ujęciu Jadwigi Puzyniny to czynność psychiczna człowieka, polegająca na stwierdzeniu, jakie (i w jakim stopniu) wartości pozytywne lub negatywne właściwe są - zdaniem osoby wartościującej - danym cechom, zachowaniom, a także pośrednio przedmiotom ${ }^{30}$.

Z kolei w rozumieniu Jerzego Bartmińskiego wartością jest „to, co w świetle języka i kultury ludzie przyjmują za cenne"31. A zatem nie tylko cechy rzeczy i same rzeczy, ale „byty pojęciowe, postawy, stany i sytuacje, zachowania, funkcjonujące jako "przewodnie idee», będące przedmiotem dążeń, chęci posiadania, motywujące postawy i zachowania ludzi, także inspirujące ich działania"32.

realizacji, Wydawnictwo Naukowe Scholar, Kraków 2009; Język w kręgu wartości, red. J. Bartmiński, Wydawnictwo UMCS, Lublin 2003; M. Karwatowska, Uczeń w świecie wartości, Wydawnictwo UMCS, Lublin 2010; J. Mariański, Sens życia, wartości, religia. Studium socjologiczne, Wydawnictwo KUL, Lublin 2013; D. Michałowska, Wartości w świecie edukacji na poczq̨tku XXI wieku, Wydawnictwo Naukowe Wydziału Nauk Społecznych Uniwersytetu Adma Mickiewicza, Poznań 2013; W. Stróżewski, W kręgu wartości, Wydawnictwo Znak, Kraków 1992.

Zob. J. Bartmiński, Miejsce wartości w językowym obrazie świata, w: tegoż, Język w kręgu wartości..., s. 58-85; J. Puzynina, Język wartości...

29 J. Puzynina, Język wartości..., s. 81.

30 Tamże, s. 83.

31 J. Bartmiński, Miejsce wartości..., s. 62.

32 Tamże. 
Wieloznaczność terminu wartość jest nie tylko jednym z powodów obecności w literaturze przedmiotu różnorodnych definicji, ale i klasyfikacji świata wartości ${ }^{33}$. Jedną z nich jest koncepcja Ryszarda Jedlińskiego, dla którego punktem wyjścia była typologia wartości zaproponowana przez Puzyninę. Autor - badając językowy obraz świata wartości uczniów kończących szkołę podstawową - opracował własną hierarchię, w której uwzględnił wyłącznie wartości pozytywne ${ }^{34}$. W dalszej części artykułu, mówiąc o aksjologicznym czytaniu powieści Hobbit, odnosić się będę do typologii wartości w ujęciu Jedlińskiego.

Ten krótki przegląd stanowisk dotyczących wartości z całą pewnością nie wyczerpuje tematu, jedynie uzmysławia, jak ważna i potrzebna zarazem jest refleksja nad nimi. Wskazana jest także dyskusja edukacyjna i zaangażowanie szkolnych polonistów, zwłaszcza że wciąż nie milkną powszechne głosy o kryzysie wartości ${ }^{35}$, kryzysie tradycyjnych instytucji edukacji i wychowania ${ }^{36}$.

W świetle powyższych ustaleń trudno zaprzeczyć, iż ważną rolę w procesie wspierania uczniów w odkrywaniu i doświadczaniu wartości odgrywających znaczącą rolę w ludzkim życiu mają do spełnienia nauczyciele, zwłaszcza poloniści,

33 Na temat definicji pojęcia wartość i prób ich klasyfikacji piszą m.in.: P. Brzozowski, Problemy hierarchizacji wartości w filozofi i psychologii, w: Język w kręgu wartości, s. 43-58; H. Buczyńska-Garewicz, Uczucia i rozum w świetle wartości. Z historii filozofii wartości, Ossolineum, Wrocław 1975; J. Gajda, Wartości w życiu człowieka. Prawda, miłość, samotność, Wydawnictwo UMCS, Lublin 1997; M. Jankowska, J. Krasoń, Hierarchia wartości i sposoby ich realizacji, Wydawnictwo Impuls, Kraków 2009; M. Karwatowska, dz. cyt.; M. Kwiatkowska-Ratajczak, dz. cyt.

34 Badacz wydzielił: I. Wartości transcendentne: Bóg, świętość, wiara, zbawienie; II. Wartości nietranscendentne: 1. poznawcze: prawda, mądrość, refleksyjność, wiedza; 2. estetyczne: piękno; 3. moralne: bohaterstwo, dobro drugiego człowieka, godność, honor, miłość, odpowiedzialność, pokora, przyjaźń, skromność, sprawiedliwość, szczerość, uczciwość, wierność; 4. społeczne: demokracja, patriotyzm, praca, praworządność, rodzina, solidarność, tolerancja, wolność; 5. witalne: siła, zdrowie, życie; 6. utylitarne (pragmatyczne): praca, spryt, talent, zaradność; 7. prestiżowe: kariera, sława, władza, majątek, pieniądze; 8. hedonistyczne: radość, seks, przygoda, zabawa, zadowolenie. Por. R. Jedliński, Językowy obraz świata wartości w wypowiedziach uczniów kończących szkołę podstawowa, Wydawnictwo Naukowe Akademii Pedagogicznej, Kraków 2000, s. 25.

35 Przykładowe tytuły tekstów na temat kryzysu wartości: E. Bendyk, Kryzys wartości, „Polityka” 2017, nr 45; Czy naprawdę mamy kryzys wartości?, https://kobietapo3o.pl/naprawde-kryzys-wartosci/; J. Kefir, Trwa dramatyczny kryzys wartości. To koniec znanego nam świata, https:// jarek-kefir.org/2016/11/18/trwa-dramatyczny-kryzys-wartosci-to-koniec-znanego-nam-swiata/; L. Kopciuch, Kryzysy, kreatywność i wartości, Wydawnictwo UMCS, Lublin 2015; N.J. Nowak, Kryzys wartości, https://www.granice.pl/publicystyka/kryzys-wartosci/374.

36 Dyskusję nad współczesnymi przemianami w sferze wartości - których przejawy można obserwować w aktualnych wydarzeniach - podjęli organizatorzy ogólnopolskiej konferencji naukowej „Kryzys wartości?”, która odbyła się na Wydziale Filozofii i Socjologii Uniwersytetu Marii Curie-Skłodowskiej w Lublinie w dniach 9-10 listopada 2017. 
gdyż ich wsparcie może przyczynić się do zaistnienia u wychowanka wewnętrznego systemu wartości, który ma szansę stać się dla niego drogowskazem wyznaczającym właściwe funkcjonowanie w świecie ${ }^{37}$. Bardzo przekonująco pisze o tym Maria Kwiatkowska-Ratajczak:

Wprowadzając dzieci i młodzież w świat wartości, ukazując ład aksjologiczny, a także formując wiedzę dotyczącą sposobów istnienia wartości w tekście literackim, przyczyniamy się jednocześnie do intelektualnego uchwycenia wartości i ich nosiciela, a zarazem - co ważniejsze - ułatwiamy ich emocjonalne odczucie ${ }^{38}$.

Cytowana autorka w swoich badaniach nad literaturą i sposobami aksjologicznego odziaływania utworów adresowanych do młodego odbiorcy podkreśla zasadność zarówno wstępnego rozpoznania potrzeb czytelniczych uczniów ${ }^{39}$, jak i konieczność projektowania aktywności lekturowych z uwzględnieniem aspektu rozwojowego dzieci i młodzieży ${ }^{40}$. „Znajomość mechanizmów rozwoju - uzasadnia Kwiatkowska-Ratajczak - umożliwia podejmowanie działań ukierunkowanych jego sposobami poznawania tekstu”, a to stanowi niezbędny warunek, aby „konstytuować młodego czytelnika jako podmiot moralny" ${ }^{\text {"11 }}$. Zdaniem autorki $Z$ perspektywy wartości o prozie dla dzieci i młodzieży szczególnie szkolny polonista powinien pokazywać uczniom rozmaite płaszczyzny powiązania człowieka ze światem wartości i prezentować różnorodne obrazy etycznych możliwości wyborów literackich bohaterów. Trudno zatem nie zgodzić się z postulatem cytowanej badaczki takiego ukierunkowania lektury utworu, aby - rekonstruując wpisaną w tekst wiedzę o wartościach - określać również aksjologiczną aktywność poszczególnych struktur literackich. Zgodnie bowiem z ustaleniami tej autorki fabuła utworu literackiego jest dominującym nośnikiem wartości przede wszystkim hedonistycznych, witalnych i moralnych. Do założeń tych odniosę się w dalszej części artykułu.

37 Zob. np. B. Komorowska. Preferowany i urzeczywistniany system wartości młodzieży gimnazjalnej podstawa poszukiwania sposobów oddziaływań wychowawczych, w: U podstaw dialogu o edukacji, red. A. Karpińska, Wydawnictwo Trans Humana, Białystok 2003, s. 232-244.

38 M. Kwiatkowska-Ratajczak, dz. cyt., s. 25.

39 M. Kwiatkowska-Ratajczak trafnie zauważa, że samo zaspokajanie potrzeb czytelniczych jest działaniem niewystarczającym, gdyż może być oznaką „schlebiania gustom” młodych ludzi, a nie ich kształtowaniem. Zob. tejże, dz. cyt., s. 61.

40 Zob. więcej w: M. Przetacznik-Gierowska, M. Tyszkowa, Psychologia rozwoju człowieka. Zagadnienia ogólne, Wydawnictwo Naukowe PWN, Warszawa 2005; Psychologia rozwoju człowieka. Charakterystyka okresów życia człowieka, red. B. Harwas-Napierała, J. Trempała, Wydawnictwo Naukowe PWN, Warszawa 2005; Psychologia rozwoju człowieka. Rozwój funkcji psychicznych, red. tychże, Wydawnictwo Naukowe PWN, Warszawa 2004; Psychologia rozwojowa dzieci i młodzieży, pod red. M. Żebrowskiej, Państwowe Wydawnictwo Naukowe, Warszawa 1982.

41 M. Kwiatkowska-Ratajczak, dz. cyt., s. 61-62. 
Jedną z lektur szkolnych, która - moim zdaniem - sprzyja aksjologicznemu czytaniu utworu literackiego jest powieść fantasy Hobbit, czyli tam i z powrotem ${ }^{42}$. Recepcja Hobbita ${ }^{43}$ w świetle badań prowadzonych nad upodobaniami czytelniczymi współczesnej młodzieży oraz moje doświadczenie związane z omawianą problematyką w szkole stały się motywacją do poszukiwania i opisania kilku strategii postępowania z tym utworem w edukacji polonistycznej w ujęciu aksjologicznym.

Dlaczego literatura fantastyczna powinna być obecna w szkole? I dlaczego warto omawiać Hobbita? Powodów wydaje się być kilka.

Badacze fenomenu popularności utworów tego gatunku ${ }^{44}$ podkreślają, że fantasy to jedno z najciekawszych zjawisk w światowej literaturze i kulturze XX i XXI wieku - stąd zasadność, aby wybrana książka ${ }^{45}$ (która ma też swoją filmową adaptację $\left.{ }^{46}\right)$ Tolkiena znalazła się centrum zainteresowań szkolnego polonisty ${ }^{47}$.

Michał Bardel, krakowski humanista i historyk filozofii, uważa, że „tajemnicą prawdziwości Tolkienowskiego mitu" jest niespieszne, stopniowe wprowadzanie

42 Lektura ta w podstawie programowej z języka polskiego z roku 2009 znajduje się wśród propozycji tekstów kultury zaproponowanych dla uczniów na II etapie edukacyjnym. Uwzględniona została także w nowej podstawie programowej z języka polskiego dla szkoły podstawowej, zatwierdzonej do realizacji od września 2017 roku.

43 Zob. np.: Forum dyskusyjne miłośników twórczości J.R.R. Tolkiena, http://forum.tolkien.com.pl/ viewtopic.php?t=3881 (dostęp 3.10.2017); Hobbicka Norka, http://www.tolkien.com.pl/hobbickanorka/index.html; K. Sokołowski, Fenomen Tolkiena, „Fantastyka” 1985, nr 2, s. 5.

44 Zob. np.: E. Korulska, dz. cyt.; G. Trębicki, Fantasy. Ewolucja gatunku, Universitas, Kraków 2010; A. Smuszkiewicz, Zaczarowana gra. Zarys dziejów polskiej fantastyki naukowej, Wydawnictwo Poznańskie, Poznań 1982; A. Smuszkiewicz, A. Niewiadomski, Leksykon polskiej literatury fantastycznonaukowej, Wydawnictwo Poznańskie, Poznań 1990; A. Szurek, Hobbit Tolkiena i Jacksona oczami ogrodnika, w: O literaturze i kulturze (nie tylko) popularnej, red. A. Gemra, A. Mazurkiewicz, Wydawnictwo Ut, Łódź 2017, s. 19-28.

45 Na temat fenomenu twórczości J.R.R. Tolkiena wypowiadali się m.in. polscy znawcy literatury i krytycy literaccy. Głos zabrał także Czesław Miłosz. W roku 2002 na łamach „Tygodnika Powszechnego", doszukując się powodów fascynacji młodych czytelników powieścią Władca Pierścieni, doszedł do wniosku, że są nimi doskonała narracja, tajemniczość świata przedstawionego i literackich bohaterów. Zdaniem Miłosza Tolkienowskie utwory są przykładem wzorcowej literatury dla młodzieży, gdyż pozbawione są pesymizmu i charakteryzują się wiernością ideałom, które we współczesnej literaturze odsyłane są najczęściej do lamusa. Por. Cz. Miłosz, Hobbit: bohater XX w., art. cyt., s. 9.

46 Tolkienowska powieść Hobbit, czyli tam i z powrotem doczekała się kilku ekranizacji, np. Hobbit - trylogia filmowa w reżyserii Petera Jacksona z roku 2012, w skład której wchodzą: Hobbit: Niezwykła podróż (cz. I), Hobbit: Pustkowie Smauga (cz. II), Hobbit: Bitwa Pięciu Armii (cz. III).

47 R. Kochanowicz, Fantastyka - klucz do wyobraźni. Poradnik dla nauczycieli języka polskiego w gimnazjum, Wydawnictwo Arka, Poznań 2001; tegoż, Fantastyczne perspektywy, „Polonistyka" 2000, nr 1, s. 43-47. 
czytelnika w świat literackich bohaterów, z którymi czytający - wraz z rozwojem wydarzeń - zaprzyjaźnia się. To sprawia, że emocjonalnie angażuje się on w przygody literackich bohaterów, wędrujących przez Śródziemie ${ }^{48}$.

Jakie mogą być inne powody, dla których warto omawiać tę powieść z uczniami? Hobbit Tolkiena to klasyk gatunku fantasy - stąd zasadność jego poznania. Ponadto, utwór posiada prostą, nieskomplikowaną budowę - stąd łatwo poddaje się wszelkim zabiegom interpretacyjnym (zarówno semantycznym, jak i formalnym).

Hobbit reprezentuje bardzo popularny wśród dzieci i młodzieży gatunek literacki, czego dowodzą liczne publikacje i ogólnopolskie raporty z badań zainteresowań czytelniczych nastolatków - stąd nauczyciel ma możliwość zainicjować wiele rozmów o tekście atrakcyjnym dla młodego czytelnika ${ }^{49}$.

Zarówno książkę Tolkiena, jaki i adaptację filmową Hobbita, wyróżnia bogactwo szczegółowych opisów miejsc i wydarzeń, a czytelnikowi towarzyszy mapa zamieszczona na końcu utworu - stąd może on rozbudzać swoją wyobraźnię, niemal doświadczać wędrówki razem $\mathrm{z}$ bohaterami.

W przeciwieństwie do przestrzeni w baśni - domyślnej i nieokreślonej - przestrzeń w Hobbicie jest wyraźna i określona. Powieściowy świat zbudowany jest z niezwykłą precyzją, wręcz z perfekcyjną dbałością o szczegóły. Każda postać, każdy ważniejszy przedmiot mają swoją historię. Tekst objaśniają zarówno dokładne mapy, jaki i drzewa genealogiczne. Mapa towarzyszy bohaterom niemal przez cały czas ich wędrówki z Bag End pod Pagórkiem do odległej Samotnej Góry ${ }^{50}$.

Rzeczywistość, w którą bez reszty zanurza się czytelnik, za sprawą swej logiki i niepowtarzalności sprawia, że czytający odnosi wrażenie osobistego uczestnictwa

48 Por. M. Bardel, Byłem hobbitem, „Hobbicka Norka”, http://www.tolkien.com.pl/hobbickanorka/artykuly/bylem.html (dostęp 10.10.2017).

49 Potwierdziła to również moja wstępna diagnoza, którą przeprowadziłam wśród 120 ostrowieckich nastolatków. W badaniach dotyczących czytelnictwa uczniów, przeprowadzonych w roku szkolnym 2015/2016 w Ostrowcu Świętokrzyskim, uczestniczyło 120 gimnazjalistów. Ponad 82\% respondentów przyznało, że lubi czytać książki i jeśli po nie sięga - to dla przyjemności (39\%) lub obowiązku zapoznania się z lekturą szkolną (42\%). Badanie preferencji czytelniczych wykazało, że gimnazjaliści (uczniowie mogli zaznaczyć 3 odpowiedzi spośród 11 możliwości) - poza lekturą szkolną - najchętniej sięgają po książkę młodzieżową (43\%), przygodową (42\%), fantasy (39\%) i kryminał (30\%). Młodzież w czytanych przez siebie utworach szuka przede wszystkim mocnych wrażeń (45\%) i ciekawych postaci (40\%).

50 Samotna Góra (inaczej Erebor) jest dawną siedzibą krasnoludów i głównym celem wyprawy bohaterów książki. W dołączonej przez autora na końcu książki mapie widać, iż Samotna Góra położona jest na równinie rozciągającej się na wschód od północnej części Mrocznej Puszczy, w niewielkiej odległości od Długiego Jeziora, stanowiąc charakterystyczny punkt Rhovanionu. Od jej głównego masywu odchodziło sześć długich ramion, a z wnętrza góry wypływała Bystra Rzeka. 
w przestrzeni literackiej i udziału w przygodach bohaterów. To właśnie droga ${ }^{51}$ wytyczona mapą przodków Thorina wiodąca bohaterów na wschód, równolegle prowadzi czytelnika i „zmusza” do jej studiowania, jakby w obawie o los wędrowców $^{52}$. Droga jest także doskonałym pretekstem do pokazania zmian w bohaterach. Im dłużej wędrują, tym większą mają wiedzę, przechodzą wiele prób, bardziej się rozwijają. Przebyta trasa hartuje bohaterów, uszlachetnia i uczy prawdziwego życia. Przewidział to zresztą zarówno czarodziej Gandalf, jak i Dwalin. Tuż po wyruszeniu w daleką podróż, kiedy tytułowy hobbit użalał się, że zapomniał kapelusza i chusteczki do nosa, krasnolud stwierdził:

Nie bądź taki dokładny [...] i nie przejmuj się drobiazgami. Nim dobrniemy do celu podróży, nauczysz się obywać bez chustki do nosa i bez wielu innych rzeczy. Jeżeli zaś chodzi o kapelusz, mam w kuferku zapasowy kaptur i płaszcz ${ }^{53}$.

Dla Tolkienowskich bohaterów wędrówka „tam i z powrotem” okazała się wielką lekcją życia. Z pewnością także dla czytelnika droga przez Śródziemie może sprzyjać przeżyciu wspólnej przygody z lekturą i odnalezieniu w niej odpowiedzi na wiele ważnych pytań, takich jak cel czy sens ludzkiego życia, gdyż - mówiąc słowami Thorina: „Jeśli się chce coś znaleźć, trzeba po prostu szukać”, choć „kto szuka, ten najczęściej coś znajdzie, niestety czasem zgoła nie to, czego mu potrzeba"54. Młody człowiek ma także możliwość współodczuwania i identyfikowania się z wędrującymi bohaterami, jednocześnie śledząc ich wędrówkę na mapie dołączonej przez autora na końcu książki. Ponadto, zachowania bohaterów są często niejednoznaczne - stąd mogą być doskonałym pretekstem do inicjowania rozmów na temat postaw i uznawanych wartości moralnych. Dzięki możliwość identyfikacji z pozytywnymi wzorcami bohaterów młody czytelnik będzie miał z pewnością okazję przekonać się, że warto dążyć do celu i że dobro zawsze zwycięża zło.

Kolejnym zatem powodem, dla którego warto omawiać z uczniami Hobbita, jest to, że utwór - choć opowiada o fantastycznych wydarzeniach dziejących się w stworzonym przez autora Śródziemiu - porusza aktualne i ponadczasowe

51 Droga, obok granicy i wieży, należy do podstawowych toposów przestrzennych w literaturze, w tym w fantasy. Jest to element o tyle ważny, że samo jej pojawienie się, niejako wymusza początek jakiejś akcji - pusty trakt oczekuje, że ktoś nim będzie szedł, prędzej czy później na drodze ktoś się pojawi. Droga jest więc związana z porządkiem czasowym, a zarazem zorganizowana w sposób linearny i ukierunkowany, gdyż zawsze prowadzi do jakiegoś miejsca (dokądś). J. Puzynina topos drogi uważa za jeden z podstawowych wyróżników ponowoczesności, por. tejże, O języku wartości w szkole, „Polonistyka” 1996, nr 4, s. 196.

52 Jest to jeden z powodów, dla których Hobbita można też określić mianem powieści drogi.

53 J.R.R. Tolkien, dz. cyt., s. 36.

54 Tamże, s. 63-64. 
problemy, takie jak wartość przyjaźni między Bagginsem a Gandalfem i krasnoludami, solidarność współtowarzyszy podróży, lojalność wobec przyjaciól, poświęcenie spokojnego życia w imię sprawiedliwości czy odwieczna walka dobra ze złem.

Co zatem może sprzyjać odnajdywaniu wartości w przestrzeni lektury? Nawiązując do założeń teoretyczno-literackich, mogą to być:

- ciekawi, niebanalni bohaterowie,

- wartka akcja (prowadzenie narracji, rozmowy bohaterów),

- przestrzeń literacka (czas i miejsca wydarzeń oraz symbolika miejsc ${ }^{55}$ ),

- trudne sytuacje, z którymi bohaterowie muszą się zmagać, np. atak wilków, spotkanie z Gollumem,

- przygody bohaterów, które mogą potęgować napięcie, pobudzać ciekawość czytelnika. Poszukując sposobów prowadzenia rozmowy z uczniami na temat lektury Hobbita i jej aksjologicznego czytania, dokonałam dość obszernej analizy projektów metodycznych - zarówno publikacji dostępnych na rynku wydawniczym bądź w bibliotekach, jak również w zasobach cyfrowych ${ }^{56}$. Ważną inspiracją było dla mnie opracowanie metodologiczno-metodyczne poświęcone dziełu Tolkiena autorstwa Ewy Korulskiej, która w książce Hobbit, czyli Wielka Przygoda z lektura wydanej w serii Metodyczna Biblioteka „To Lubię!” zaproponowała ciekawe strategie pracy $\mathrm{z}$ tą lekturą. Autorka pokazała szkolnym polonistom różnorodne formy aktywności z powieścią Hobbit na kilku poziomach, w zależności od potrzeb i zainteresowań uczniów - czytanie „panoramiczne” (ogarniające cały utwór) i czytanie „przez lupę" (skupiające uwagę na fragmentach i detalach). Analiza publikacji metodycznych uświadomiła mi bowiem, że nie zawsze aspekt wartości dostrzegany jest przez autorów licznych i bardzo zróżnicowanych projektów metodycznych. Chciałabym zatem bardziej wyeksponować wymiar aksjologiczny tego utworu, uwzględniając jednocześnie współczesne realia społeczno-kulturowe, w których funkcjonuje dzisiejszy uczeń. Mam tu na uwadze przede wszystkim (współ)obecność wirtualnego

55 Ważnymi symbolami w utworze mogą być m.in. dom hobbita - norka w wiosce Bag End pod Pagórkiem (przestrzeń wewnętrzna, prywatna, dająca bohaterowi poczucie intymności), jaskinia Golluma, Samotna Góra (inaczej Erebor, dawna siedziba krasnoludów i główny cel wyprawy bohaterów książki).

56 Zob. np. R. Jarząbek, Scenariusz lekcji poświęconych omówieniu lektury „Hobbit, czyli tam i z powrotem" J.R.R. Tolkiena, http://www.interklasa.pl/portal/index/dokumenty/interklasa/hobbit.doc?page=info\&action=showdoc\&oid=240682 (dostęp 12.09.2017); E. Korulska, dz. cyt.; J. Piasta-Siechowicz, M. Iwasiewicz, Praca z lektura i jej filmowa adaptacja według OWD (Ocenianie w Dialogu). „Hobbit”, „Język Polski w Szkole IV-VI. Zeszyty Kieleckie” 2016/2017, nr 3 , s. 42-59; J. Piasta-Siechowicz, G. Miszczyk, Wyprawa z Hobbitem, „Język Polski w Szkole IV-VI” 2003/2004, nr 2, s. 62-68; Scenariusz lekcji: Bilbo Baggins w książce i internecie, http://www. scholaris.pl/zasob/64683?bid=o\&iid=\&query=Hobbit\&api= (dostęp 12.09.2017); A. Sobańska, Szkolne Śródziemie. Gra literacka, „Biblioteka w Szkole” 2015, nr 10, s. 28-30. 
świata, w który tak ochoczo i często zanurza się młody człowiek, powszechnie nazywany cybertubylcem czy sieciakiem. Te uwarunkowania dają, w moim przekonaniu, podstawę do tego, aby w polonistycznym warsztacie metodycznym wykorzystywać takie metody, formy pracy i środki dydaktyczne, które dotyczą również cyfryzacji. Stąd w moich propozycjach, zgodnie z koncepcją szkoły drugiej generacji, postulat obecności nowoczesnych technologii przy wykorzystaniu tradycyjnych technik - sprawdzonych i popularnych w edukacji polonistycznej.

Jak zatem można wyzwalać wrażliwość aksjologiczną? I w jaki sposób lektura może stać się nośnikiem wartości w szkolnej edukacji polonistycznej?

Podejmę próbę odpowiedzi na tak postawione pytania na przykładzie własnych doświadczeń dydaktycznych jako nauczycielki języka polskiego. Rekomendowany przeze mnie model pracy $z$ tą lekturą uwzględnia:

1) aspekt motywacyjny, w tym rolę czytania domowego i jego ukierunkowanie, na przykład poprzez polecanie uczniom wortali literackich i stron internetowych poświęconych dziełom Tolkiena ${ }^{57}$ oraz literackiej przestrzeni ${ }^{58}$, zachęcanie do czytania recenzji internautów na temat rekomendowanej powieści ${ }^{59}$, włączanie się do dyskusji na temat lektury, pisanie własnej opinii o Hobbicie, wyszukiwanie w utworze ciekawych, ważnych - zdaniem uczniów - cytatów, wśród których znajdą się te świadczące o przyjaźni, lojalności, uczciwości, odwadze, bohaterstwie;

2) cykl lekcji poświęconych lekturze, dowartościowujący następujące formy aktywności ucznia: swobodne wypowiedzi o lekturze, dyskusja inicjowana sytuacją lub postawą bohatera, projektowanie alternatywnych rozwiązań fabularnych oraz problemowych inspirowanych utworem;

3) pozalekcyjną aktywność własną, ukierunkowaną na kształcenie kreatywności uczniów poprzez różnorodne działania intersemiotyczne, takie jak: opracowanie komiksu lub gry planszowej odwołującej się do fabuły Hobbita, przygotowanie wywiadu z Bilbo Bagginsem po jego szczęśliwym powrocie do rodzinnego Pagórka, zorganizowanie konkursu inspirowanego zagadkami Golluma i Bagginsa. W moim odczuciu proponowane formy - jeśli będą uwzględniać zainteresowania i predyspozycje młodych ludzi - mogą być dla młodzieży atrakcyjne i z dużym prawdopodobieństwem przyczynią się do rozbudzania zainteresowań uczniów światem wartości moralnych literackich bohaterów, a tym samym będą wspierać proces kształtowania umiejętności aksjologicznego czytelnia literatury.

57 Wybrane strony poświęcone szeroko rozumianej tolkienistyce: „Ennorath”, http://tolkien. com.pl/ennorath/index.php; „Hobbicka Norka”, http://www.tolkien.com.pl/hobbickanorka/; „Ostatni Przyjazny Dom”, http://www.tolkien.cyberdusk.pl/.

58 Zob. Interaktywna mapa Śródziemia, http://www.lokalizacja.info/pl/rynek-masowy/tech/ mapa-srodziemia-nie-tylko-dla-fanow-tolkiena.html\#.WgbZUWjWzIU.

59 Zob. np. http://efantastyka.pl/art_hobbit-czyli-tam-i-z-powrotem-jrr-tolkien. 
Rozpoczynając szkolną przygodę z lekturą Hobbita, warto przede wszystkim doceniać znaczenie czytania intuicyjnego i zapytać ucznia o pierwsze wrażania. Jest to wstępny etap, na którym pojawią się wartości i wartościowanie, gdyż uczeń wyraża opinie o lekturze i bohaterach, a także wartościuje, uzasadnia. Warto pozwolić wychowankowi, aby w sposób nieskrępowany dokonał oceny. Dobrym rozwiązaniem mogą być nie tylko wypowiedzi ustne, ale także anonimowe opinie pisemne ${ }^{60}$ (dokańczanie zdań, np.: Hobbit to utwór o...; Dzięki powieści zrozumiałem/łam, że...; W powieści najbardziej zaciekawiło mnie...; Uważam, że książka jest...) . Sądzę, że może to być ciekawy wstęp do projektowania dalszych czynności ukierunkowanych na kształcenie umiejętności mówienia o wartościach ${ }^{61}$.

Dopełnieniem krótkich ćwiczeń leksykalnych mogą być dłuższe wypowiedzi uczniowskie. Proponuję następujące dyspozycje: I. Napisz opowiadanie o przygodach bohaterów na jeden z poniższych tematów: 1) Nie ma tego złego, co by na dobre nie wyszło; 2) Prawdziwych przyjaciół poznaje się w biedzie. II. Napisz, z którym powieściowym bohaterem mógłbyś się zaprzyjaźnić i dlaczego. Tak sformułowane propozycje zadań z pewnością wyzwolą uczniowską kreatywność, a także pośrednio pozwolą odnieść się młodemu człowiekowi do problematyki aksjologicznej i etycznej. Mam tu na uwadze na przykład projektowanie własnego zakończenia Tolkienowskiej historii i ćwiczenia symulacyjne. W wersji tradycyjnej mogłyby to być dyspozycje: 1) „Moje zakończenie” - na podstawie Hobbita napisz nowe, zaskakujące zakończenie przygód bohaterów; 2) Wyobraź sobie, że Bilbo Baggins nie przyłączył się jednak do wędrowców. Jak, Twoim zdaniem, mogłoby to wpłynąć na jego życie? Opisz jego historię w dowolnej formie (np. list, karta z pamiętnika, opowiadanie); 3) Jak Ty postąpiłbyś na miejscu bohatera? Do kwestii tej odwołam się jeszcze w dalszej części artykułu. Możliwości doskonalenia postaw aksjologicznych uczniów otwierają się bowiem przy okazji odniesień do sytuacji niebezpiecznych, a nawet zagrażających życiu, w które uwikłani zostają fikcyjni bohaterowie.

Jako szkolny polonista na co dzień doświadczam uczniowskiej niechęci wobec czytania, dlatego uważam, że warto także poszukiwać ciekawych form motywowania wychowanków do lektury - zarówno książki, jak i/lub ekranizacji powieści, ale i zachęcać do czytania o lekturze w intrenecie. Jestem przekonana, że szczególnie w sytuacjach gdy tradycyjne strategie dydaktyczne zawodzą, nauczyciel powinien otworzyć się nowe na narzędzia technologiczne. Nie warto krytykować i „walczyć”

60 Praktyka nauczycielska pokazuje, iż anonimowość wypowiedzi sprawia, że uczeń dokonuje oceny zgodnie ze swoim wewnętrznym odczuciem, a nie wartościuje, niejako przewidując oczekiwania nauczyciela. Należy oczywiście liczyć się także z tym, że uczniowskie odpowiedzi będą dla szkolnego polonisty zaskakujące, ale też uczeń może w ogóle zrezygnować z wyrażenia swojego stanowiska.

61 Zob. np. J. Puzynina, Język wartości... 
ze zdobyczami „epoki cyfrowej”. Dobrze by było, gdyby nauczyciele, organizując szkolne spotkania z lekturą współczesnych nastolatków, dowartościowywali rolę tradycyjnych i nowych mediów, którymi zafascynowane jest „pokolenie sieci”. Warto dziś w równym stopniu upowszechniać informacje o książkach jako zdobyczach Gutenberga i domenie mediów elektronicznych ${ }^{62}$.

Szkolny polonista może zaproponować wiele ciekawych zadań, które zachęcą „tabletowe dzieci” do aktywnego odbioru tekstu kultury. Zasadne wydaje się zatem, aby w kształceniu kulturowo-literackim częściej wykorzystywać film ${ }^{63}$ oraz cyfrowe środki dydaktyczne, takie jak prezentacja multimedialna ${ }^{64}$. Przykładem takiej dyspozycji może być prośba o zaznaczenie (wynotowanie) fragmentu (a może fragmentów?), które najbardziej poruszyły czytającego Hobbita i/lub oglądającego film czy też wypisanie zdania mogącego, w odczuciu ucznia, stać się jego dewizę życiową. Z pewnością warto wykorzystać też strategię czytania kontekstowego ${ }^{65}$. Należy założyć, że zachęceni przez nauczyciela uczniowie zechcą wzbogacić swoje autorskie prezentacje elementami graficznymi, zdjęciami różnych okładek Tolkienowskiej książki, fotosem filmowym, fragmentem ścieżki dźwiękowej bądź wybranej sceny z filmu. Szkolne projekty, eksponujące teksty ikonograficzne, to dobra okazja do aksjologicznego czytania Hobbita. Uczniowie mogą na przykład dyskutować na temat tego, co - ich zdaniem - było ważne dla postaci literackich, jakiej wiedzy na temat postaw i wyznawanych przez bohaterów wartości dostarczają przyszłym czytelnikom ilustracje zamieszczone na okładkach książek czy fotosy filmowe.

62 Szerzej na ten temat piszą m.in.: B. Gromadzka, Jak nowe media i kultura współuczestnictwa wpływaja na kształcenie polonistyczne?, w: Edukacja a nowe media, red. M. Latoch-Zielińska, I. Morawska, M. Potent-Ambroziewicz, Wydawnictwo UMCS, Lublin 2015, s. 79-89; I. Morawska, Wpływ nowych mediów na doświadczenia kulturowe współczesnych nastolatków, w: Człowiek i kultura w komunikacji medialnej, red. M. Karwatowska, R. Litwiński, A. Siwiec, Wydawnictwo UMCS, Lublin 2015, s. 221-232.

63 Nasza tradycja literacka zazwyczaj sytuuje film w bliskim sąsiedztwie literatury. Powszechna jest także teza, że film (wraz z radiem i telewizją) zdominował literaturę. Warto więc stworzyć uczniom możliwość rozmowy na temat adaptacji filmowej Tolkienowskiego dzieła. Film stanie się wówczas nie tylko doskonałym uzupełnienie lekcji, niewątpliwie też alternatywnym rozwiązaniem dla poszukiwań wartości wpisanych w lekturę.

64 Interesujące strategie wykorzystania prezentacji multimedialnej w pracy z lekturą szkolną w erze cyfrowej proponuje A. Pedemska-Kałuża, Zaproszenie do lektury z wirtualnego świata, „Polonistyka” 2017, nr 5, s. 25-29.

65 Zob. np. W. Bobiński, Konteksty kulturowe w dydaktyce literatury, w: Polonista w szkole. Podstawy kształcenia nauczyciela polonisty, red. A. Janus-Sitarz, Universitas, Kraków 2004; S. Bortnowski, Konteksty dzieła literackiego. Inspiracje metodyczne dla nauczycieli szkół średnich, Wydawnictwa Szkolne i Pedagogiczne, Warszawa 1991; E. Korulska, Kontekstowe czytanie kultury, „Nowa Polszczyzna" 1997, nr 5, s. 35-39; Konteksty polonistycznej edukacji, pod red. M. Kwiatkowskiej-Ratajczak, S. Wysłouch, Wydawnictwo Poznańskie, Poznań 1998. 
Dopełnieniem propozycji uwzględniania strategii kontekstowej w pracy z lekturą Hobbita może być również przekład intersemiotyczny ${ }^{66}$. Uczniowie mogą tworzyć plakaty lub komiksy inspirowane sytuacjami wymagającymi podjęcia ważnej decyzji, przez to trudnymi dla fikcyjnych bohaterów ${ }^{67}$.

Tworzone projekty edukacyjne $\mathrm{z}$ pewnością mogą pomagać odnajdywać w przestrzeni lektury przede wszystkim wartości moralne, co sprzyja dyskusjom na temat motywów postępowania bohaterów oraz konsekwencji podjętych przez nich decyzji. Jakie inne metody może tu zastosować nauczyciel? Możliwości wydaje się być wiele - „myślenie obrazami”"68, wywiad, pytania do tekstu, bohatera literackiego lub autora. Sprzymierzeńcem w pracy szkolnego polonisty zapewne będą także nowoczesne technologie, alternatywne dla tradycyjnych metod, form i narzędzi dydaktycznych. Duże szanse dostrzegam w wykorzystaniu na lekcji gamifikacji69, która jest nośnikiem wartości hedonistycznych, wyzwala pozytywne emocje, a te z kolei ułatwiają proces uczenia się. Wykorzystywanie elementów gry (zabawy, rozrywki) sprawia, że proces uczenia się przestaje być jedynie obowiązkiem, a staje się ciekawą formą przyswajania wiedzy, dzięki czemu człowiek uzyskuje lepsze efekty ${ }^{70}$. Aktywności takie mają nie tylko walor poznawczy, wyzwalają także emocje (a te zdaniem psychologów są niezbędne w procesie uczenia się), które pozwalają młodym ludziom identyfikować się z bohaterami, lepiej zrozumieć ich postawy, uznawane wartości. To z kolei może stać się początkiem dyskusji o potrzebach, wartościach, życiowych celach czy pragnieniach.

Dobrą formą wyzwalającą uczniowską kreatywność, rozbudzającą zainteresowanie fabułą utworu i wspomagającą nauczyciela w aksjologicznym czytaniu Hobbita, może być - co także potwierdza moja praktyka szkolna - metoda fabuła

66 Przekład intersemiotyczny może być zadaniem łatwym do wykonania niemal dla wszystkich uczniów, nie tylko posiadających predyspozycje czy zdolności artystyczne. Pomocne dla ucznia mogą być nowoczesne technologie i programy graficzne. Zapewne interesujące prace powstaną w formie komiksu wykonanego za pomocą programu PIXTON lub Toon Doo.

67 Taką sytuacją może być na przykład dylemat tytułowego hobbita: Zostać w domu i wieść spokojne życie czy wyruszyć w nieznane, aby pomóc krasnoludom w odzyskaniu przez nich skradzionych skarbów przodków?

68 Metoda ta koncentruje pracę wokół trzech pytać: 1) Co wiesz na pewno? 2) Czego się domyślasz? 3) Czego chciałbyś/chciałabyś jeszcze się dowiedzieć?

69 Gamifikacja (określana także jako grywalizacja lub gryfikacja) to dość popularne działanie, funkcjonujące $z$ powodzeniem w życiu społecznym. Polega na zamierzonym zastosowaniu w trakcie projektowania gier takich mechanizmów i technik, które mają walory motywujące, uprzyjemniają nieciekawe czynności, a także powodują zwiększenie zaangażowania. Jej założeniem jest takie ukierunkowanie i mobilizacja działań uczestników, aby cel został osiągnięty.

70 Zob. A. Kubala-Kulpińska, Gra w szkołę, czyli jak wykorzystać gamifikację na lekcji, „Polonistyka” 1/2017, nr 16, s. 36-39. 
$z k u b k a^{71}$, alternatywna dla popularnej gry Story Cubes ${ }^{72}$ czy metody Storyline ${ }^{73}$. Szczególnie ostatnia z metod może okazać się ciekawym przeżyciem dla uczniów, jeśli zechcą na przykład „założyć” własne biuro turystyczne, pracować w nim i przygotować atrakcyjną ofertę wycieczki do Tolkienowskiego Śródziemia. Warto przy tej okazji porozmawiać z uczniami na temat przestrzeni Śródziemia, która uosabia spotkanie z niewiadomym, jest synonimem niebezpieczeństwa czyhającego w każdej chwili na bohaterów, ale także zaproszeniem do przeżycia przygody i poznania nieznanego świata. Atak goblinów i wilków, groźba utraty życia w pajęczej sieci czy spotkanie w mrocznym lochu z Gollumem - to jedynie wybrane momenty w życiu powieściowych postaci, dzięki którym nauczyciel może zastosować „trening aksjologiczny”. Lektura Hobbita motywuje więc do aktywności, pozwala rozwijać uczniowską ciekawość, a poznawanie świata i odwaga w sytuacjach zagrażających własnemu życiu lub życiu innych to powszechnie uznawane wartości: poznawcze, moralne, społeczne, witalne - i na to warto zwracać uwagę młodym ludziom.

Niewątpliwie problemem zasługującym na refleksję aksjologiczną jest również zachowanie Bilba wobec czyhającego na jego życie Golluma. Warto, moim zdaniem, zadać pytania: Jak oceniasz zachowanie hobbita wobec Golluma? Na czym, Twoim zdaniem, polega prawdziwa odwaga? Warto pozwolić uczniom wypowiedzieć się na temat motywów postępowania, etyki hobbita, ale także dowiedzieć się, w jaki sposób współczesny młody człowiek zachowałby się w podobnej sytuacji. Ciekawym doświadczeniem może być także poznanie uczniowskich opinii na temat słów wypowiedzianych w filmie przez Gandalfa na temat konfrontacji tytułowego bohatera z Gollumem i darowania mu życia przez niziołka: „Prawdziwą odwagą nie jest kogoś zabić, lecz wiedzieć, kiedy darować życie"”74. Dobrze jest też odnieść się do celu i sensu wędrówki, pytając uczniów: Co - Twoim zdaniem

71 Fabuła z kubka jest metodą, która kształci umiejętność układania opowiadań. Z różnych elementów świata przedstawionego (postacie, cechy charakteru, sposób działania bohaterów, miejsca akcji, komplikacje) powstaje nowa fabuła, np. inne zakończenie omawianego tekstu literackiego. Zastosowanie tej metody umożliwia rozwijanie wyobraźni, a także zachęca do aktywnej pracy na lekcji. Uczniowie doskonalą również umiejętność logicznego myślenia, kojarzenia faktów oraz formułowania wniosków.

72 Story Cubes to obecnie popularna gra, składająca się z sześciennych kostek, z których każda zawiera na ściankach odmienny zestaw ilustracji. Zadaniem gracza jest snucie opowieści, rozpoczętej np. słowami „Dawno, dawno temu...” lub „Pewnego razu...”, której fabuła będzie kontynuowana w oparciu o dziewięć obrazów wylosowanych na kostkach. Gracz może rozpocząć swoją historie w dowolnym miejscu, w zależności od tego, który obrazem przykuł jego uwagę. Głównym założeniem metody Storyline jest samodzielna aktywność uczniów i wykorzystywanie ich naturalnego entuzjazmu. Uczniowie sami są tu głównymi postaciami w opowiadanej przygodzie/historii (story), a jeśli tak nie jest, muszą sobie te postacie wymyślić.

74 Por. film Hobbit: Niezwykła podróż. 
- motywowało bohaterów wyruszających na wschód? Jaką lekcję - według Ciebie - wynieśli z podróży „tam i z powrotem”? Tak sformułowane problemy z pewnością będą motywowały do mówienia o wartościach, umożliwią „język wartości”, skłonią do refleksji nad wartościami m.in. moralnymi i społecznymi.

Ciekawym pomysłem może być także zainicjowanie przez nauczyciela opowieści inspirowanej niespodziewaną obecnością krasnoludów w norce hobbita, co stanie się zapewne okazją do rozmowy o wartościach społecznych. Zadaniem kreacyjnym dla uczniów może być wówczas stworzenie historii, rozpoczynającej się od nakreślenia sytuacji wyjściowej (inspirowanej lekturą Hobbita ${ }^{75}$ ). Nauczyciel może tak sformułować polecenie: Dokończ opowieść, której początek może stanowić wstęp: „Jest środa. Wczesny poranek. Bilbo Baggins skończył właśnie jeść śniadanie, gdy przypomniał sobie, że poprzedniego dnia nieopatrznie zaprosił Gandalfa na herbatę...”. Przywołanie okoliczności pojawienia się w norce tytułowego hobbita niespodziewanych gości z pewnością pozwoli nauczycielowi zainicjować rozmowę na temat gościnności i zasad właściwego zachowania. Stanowi to również dobrą okazję do twórczej dyskusji wokół omawianego problemem: W jaki sposób postąpiłbyś (postąpiłabyś), będąc na miejscu Bagginsa, gdyby do Twojego domu nagle przybywali nieproszeni goście? Inną dyskusję może zainicjować dylemat: Nieproszeni goście - dobrodziejstwo (radość) czy udręka (problem) gospodarza?

Warto w tym miejscu odnieść się do popularnej metody drzewka decyzyjnego. Jej zastosowanie umożliwi uczniom zmierzyć się z problemem, którego doświadczył hobbit. Postawmy zatem prowokacyjne pytanie: Jak powinien, Twoim zdaniem, postąpić Bilbo Baggins - wyruszyć w nieznane z krasnoludami czy pozostać we własnym domu. Metody aktywizujące, do których zalicza się drzewko decyzyjne, mają niezaprzeczalne walory edukacyjne - uczą samodzielnego poszukiwania rozwiązań, pozwalają dostrzec związki między rozwiązaniami oraz skutki przyjętego rozwiązania (zarówno pozytywne, jaki i negatywne), wyzwalają nie tylko kreatywność, także prowokują ucznia do refleksji na temat celów i wartości uznawanych przez osobę podejmującą decyzję.

Zadania inspirowane różnorodnymi metodami i wykorzystujące zarówno tradycyjne, jak i nowoczesne technologie, wyzwalające uczniowską ciekawość, zapewne sprawią, że młody człowiek odkryje różnorodne wartości, których nośnikiem jest rekomendowana przeze mnie lektura. Ponadto takie niekonwencjonalne metody pracy mogą przeciwdziałać szkolnej nudzie, gdyż atrakcyjne jest przede wszystkim to, co nowe, dalekie od rutyny.

Świadectwem odbioru proponowanej przeze mnie Tolkienowskiej powieści mogą być przykładowe wypowiedzi uczniów. Poproszeni o krótką refleksję, czy i dlaczego warto przeczytać Hobbita, najczęściej udzielali odpowiedzi: jest to fajna 
przygoda, która nas uczy, że zawsze trzeba być sobą; jest to fantastyczna opowieść, która potrafi przenieść $w$ inny świat; książka pobudza wyobraźnię; ciagle coś się tam dzieje; jest to lektura szkolna, ale daje do myślenia; chciałbym mieć takich przyjaciót jak Hobbit, bo zawsze mógłbym na nich liczyć.

Edukacja aksjologiczna jest ciągłym wyzwaniem, przede wszystkim dla szkolnego polonisty. Zaprezentowane przeze mnie przykładowe strategie pracy z powieścią fantasy są przykładem wydobywania $\mathrm{z}$ lektury walorów aksjologicznych. Uważam, że zbyt rzadko problematykę wartości eksponuje się w edukacji kulturowo-literackiej. Dlatego proponuję jeszcze większe zaangażowanie - warto wciąż postulować o to, aby na lekcji uczeń jak najczęściej mógł doświadczać wartości. Moim zdaniem powieść Tolkiena jest dobrym narzędziem pozwalającym nauczycielowi zarówno wprowadzać ucznia w świat wartości, jak i kształtować jego świadomość aksjologiczną. Sprzyjać jednak temu będą przemyślane i niebanalne aktywności, które zmotywują ucznia do lektury i wyzwolą przyjemność czytelniczą. Szkolna sztampa, frazesy i bezrefleksyjność ze strony nauczyciela mogą, niestety, przyczynić się do pogłębiania uczniowskiej niechęci wobec lektury szkolnej.

\section{Bibliografia}

Bardel Michał, Byłem hobbitem, „Hobbicka Norka”, http://www.tolkien.com.pl/hobbickanorka/artykuly/bylem.html (dostęp 10.10.2017).

Bartmiński Jerzy, Język w kręgu wartości. Studia semantyczne, Wydawnictwo UMCS, Lublin 2003.

Bobiński Witold, Konteksty kulturowe w dydaktyce literatury, w: Polonista w szkole. Podstawy kształcenia nauczyciela polonisty, red. Anna Janus-Sitarz, Universitas, Kraków 2004, s. 217-237.

Chrząstowska Bożena, Wartości odkrywane, narzucone i postulowane w szkolnejedukacji polonistycznej, w: Polonistyka w przebudowie. Literaturoznawstwo - wiedza o języku - wiedza o kulturze - edukacja, red. Małgorzata Czermińska i in., t. 2, Universitas, Kraków 2005, s. 306-322.

Fantasy. Ilustrowany przewodnik, red. Andrzej Miszkurka, Arkady, Warszawa 2003. Głowiński Michał, Okopień-Sławińska Aleksandra, Sławiński Janusz, Zarys teorii literatury, Wydawnictwa Szkolne i Pedagogiczne, Warszawa 1975.

Gromadzka Beata, Jak nowe media i kultura wspótuczestnictwa wplywaja na kształcenie polonistyczne?, w: Edukacja a nowe media, red. Małgorzata Latoch-Zielińska, Iwona Morawska, Małgorzata Potent-Ambroziewicz, Wydawnictwo UMCS, Lublin 2015, s. 79-89.

Handke Ryszard, Lektura jako poznanie i samopoznanie, w: Podmiotowy wymiar szkolnej polonistyk. Materiały z konferencji: Antropocentryczno-kulturowy nurt 
w kształceniu polonistycznym, red. Zenon Uryga, Wydawnictwo Naukowe Wyższej Szkoły Pedagogicznej, Kraków 1998, s. 97-104.

Interpretacje aksjologiczne, red. Władysław Panas, Andrzej Tyszczyk, Wydawnictwo KUL, Lublin 1997.

Janus-Sitarz Anna, Przyjemność i odpowiedzialność w lekturze. O praktykach czytania literatury w szkole. Konstatacje. Oceny. Propozycje, Universitas, Kraków 2009. Janus-Sitarz Anna, Wartościowanie a edukacja polonistyczna, Universitas, Kraków 2008.

Jedliński Ryszard, Językowy obraz świata wartości w wypowiedziach uczniów kończacych szkołe podstawowa, Wydawnictwo Naukowe Akademii Pedagogicznej, Kraków 2000.

Kłakówna Zofia Agnieszka, Kulturowa koncepcja kształcenia polonistycznego, w: Polonistyka w przebudowie. Literaturoznawstwo - wiedza o jezyku - wiedza o kulturze - edukacja, red. Małgorzata Czermińska i in., t. 2, Universitas, Kraków 2005, s. 74-84.

Kochanowicz Rafał, Fantastyka - klucz do wyobraźni. Poradnik dla nauczycieli języka polskiego w gimnazjum, Wydawnictwo Arka, Poznań 2001.

Korulska Ewa, Hobbit, czyli Wielka Przygoda z lektura, Wydawnictwo Edukacyjne, Kraków 1998.

Kubala-Kulpińska Aleksandra, Gra w szkołę, czyli jak wykorzystać gamifikację na lekcji, „Polonistyka” 1/2017, nr 16, s. 36-39.

Kwiatkowska-Ratajczak Maria, $Z$ perspektywy wartości o prozie dla dzieci i młodzie$\dot{z} y$, Wydawnictwo Nakom, Poznań 1994.

Leszczyński Grzegorz, Zając Michał, Książka i młody czytelnik: zbliżenia, oddalenia, dialogi. Studia i szkice, Wydawnictwo Stowarzyszenia Bibliotekarzy Polskich, Warszawa 2013.

Miłosz Czesław, Hobbit: bohater XX w., „Tygodnik Powszechny” 2002, nr 8, s. 1-9.

Morawska Iwona, Wplyw nowych mediów na doświadczenia kulturowe wspótczesnych nastolatków, w: Człowiek i kultura w komunikacji medialnej, red. Małgorzata Karwatowska, Robert Litwiński, Adam Siwiec, Wydawnictwo Uniwersytetu Marii Curie-Skłodowskiej, Lublin 2015, s. 221-232.

Myrdzik Barbara, Nauczyciel jako organizator dialogu ucznia z tradycja, w: Nowoczesność i tradycja w kształceniu literackim. Podręcznik do ćwiczeń $z$ metodyki języka polskiego, red. Barbara Myrdzik, Wydawnictwo UMCS, Lublin 2000, s. 175-187.

Myrdzik Barbara, O poznawaniu i doświadczaniu wartości w procesie edukacyjnym, w: Barbara Myrdzik, Zrozumieć siebie i świat, Wydawnictwo UMCS, Lublin 2006, s. 88-132.

Pedemska-Kałuża Anna, Zaproszenie do lektury z wirtualnego świata, „Polonistyka” 2017, nr 5, s. 25-29.

Podstawa programowa. Język Polski. Szkoła podstawowa - klasy IV-VIII, Ministerstwo Edukacji Narodowej, Warszawa 2017. 
Podstawa programowa z komentarzami. Język Polski, t. 2, Ministerstwo Edukacji Narodowej, Warszawa 2009.

Problematyka aksjologiczna $w$ nauce o literaturze. Studia, red. Stefan Sawicki, Andrzej Tyszczyk, Wydawnictwo KUL, Lublin 1992.

Przygotowanie ucznia do odbioru różnych tekstów kultury, red. Anna Janus-Sitarz, Universitas, Kraków 2004.

Puzynina Jadwiga, Język wartości, Państwowe Wydawnictwo Naukowe, Warszawa 1992.

Puzynina Jadwiga, O języku wartości w szkole, „Polonistyka” 1996, nr 4, s. 196-201.

Puzynina Jadwiga, Słowo - wartość - kultura, Towarzystwo Naukowe Katolickiego Uniwersytetu Lubelskiego, Lublin 1998.

Sawicki Stefan, Aksjologiczne wymiary literatury, w: Polonistyka w przebudowie. Literaturoznawstwo - wiedza o języku - wiedza o kulturze - edukacja, red. Małgorzata Czermińska i in., t. 2, Universitas, Kraków 2005, s. 298-305.

Sawicki Stefan, Problematyka aksjologiczna $w$ badaniach literackich, w: Problematyka aksjologiczna $w$ nauce o literaturze. Studia, red. Stefan Sawicki, Andrzej Tyszczyk, Towarzystwo Naukowe Katolickiego Uniwersytetu Lubelskiego, Lublin 1992, s. 95-101.

Słownik literatury popularnej, red. Tadeusz Żabski, Wydawnictwo Towarzystwo Przyjaciół Polonistyki Wrocławskiej, Wrocław 2006.

Smuszkiewicz Antonii, Fantastyka i pajdologia. Studia i szkice, Poznańskie Studia Polonistyczne, Poznań 2013.

Smuszkiewicz Antoni, Fantastyka w gimnazjum, w: Horyzonty polonistyki. W kregu edukacji, języka i kultury, red. Małgorzata Karwatowska, Małgorzata Latoch-Zielińska, Iwona Morawska, Wydawnictwo UMCS, Lublin 2010, s. 143-159.

Stoff Andrzej, Wartości sytuacyjne dzieła literackiego, w: Problematyka aksjologiczna w badaniach literackich, red. Stefan Sawicki, Towarzystwo Naukowe Katolickiego Uniwersytetu Lubelskiego, Lublin 1992, s. 111-135.

Szurek Agnieszka, Polska dyskusja o fantasy w latach 1990-2002, http://www.tolkien.com.pl/hobbickanorka/artykuly/pols.html, (dostęp 2.05.2017).

Tolkien John Ronald Reuel, Hobbit, czyli tam i z powrotem, przeł. Maria Skibniewska, Wydawnictwo Iskry, Warszawa 1997.

Wartość i sens. Aksjologiczne aspekty teorii interpretacji, red. Edward Fiała, Andrzej Tyszczyk, Ryszard Zajączkowski, Wydawnictwo KUL, Lublin 2003. 


\title{
Lektura szkolna jako nośnik wartości Na przykładzie powieści Johna Ronalda Reuela Tolkiena Hobbit, czyli tam i z powrotem
}

\author{
Streszczenie
}

Celem artykułu jest próba ukazania wybranych strategii dydaktycznych związanych z wprowadzaniem uczniów w świata wartości, których nośnikiem są omawiane na lekcjach języka polskiego lektury. Problem ten został omówiony na przykładzie powieści fantasy J.R.R. Tolkiena Hobbit, czyli tam i z powrotem. Badania nad recepcją tej książki w Polsce przez współczesnych nastolatków oraz moje doświadczenie związane z omawianą problematyką stały się motywacją do opisania kilku - jak sądzę ciekawych - strategii postępowania $\mathrm{z}$ tą lekturą $\mathrm{w}$ edukacji polonistycznej w ujęciu aksjologicznym.

Słowa kluczowe: lektura szkolna, edukacja aksjologiczna, wartości, fantasy, nastolatek, współczesność

\section{The required reading as a carrier of values on the example of The Hobbit or There and Back Again novel by J.R.R. Tolkien}

Summary

The purpose of this article is an attempt to show what role required reading can play as a carrier of values in the literacy and cultural education of teenagers. This problem will be discussed on the example of fantasy novel The Hobbit or There and Back Again by J.R.R. Tolkien. Research on the reception of this book in Poland by contemporary teenagers and my experience with the discussed issues have motivated me to describe a few - interesting in my opinion - strategies for dealing with this novel in Polish language education in axiological terms.

Keywords: required reading, axiological education, values, fantasy, teenager, contemporary times 
Edyta Wójcicka, mgr, absolwentka filologii polskiej i etyki. Doktorantka w Katedrze Edukacji Polonistycznej UMCS w Lublinie. Wieloletni doradca metodyczny i nauczycielka języka polskiego we wszystkich typach szkół. Wizytator Wydziału Rozwoju Edukacji w Mazowieckim Kuratorium Oświaty. Zainteresowania naukowe: dydaktyka literatury, aksjologia literacka. Autorka wielu publikacji naukowych i metodycznych, w tym dwóch książek: Rola mediów społecznościowych w kształtowaniu kultury czytelniczej nastolatków, „Folia Bibliologica” 2017, t. VIX, s. 135-151; Wokół Szkiców o dojrzałości, kulturze i szkole. Refleksje, badania, inspiracje, „Acta Humana” 2017, nr 8, s. 265-270; Aneta Pierścińska-Maruszewska, Edyta Wójcicka, Trzymaj styl. Praktyczna nauka poprawnej polszczyzny, Wydawnictwo Pedagogiczne Związku Nauczycielstwa Polskiego, Kielce 2013; Zostań mistrzem ortografii. Zbiór dyktand do praktycznej nauki poprawnej pisowni dla ucznia, rodzica i nauczyciela, Wydawnictwo Pedagogiczne Związku Nauczycielstwa Polskiego, Kielce 2018. 